\title{
Democracy and Dictatorship in Latin America
}

Prepared in collaboration with Vuelta, the Mexican magazine edited by Octavio Paz, this collection reflects a natural divergence of opinion but also a passionate commitment to political freedom and democratic social change.

Contributors (all Latin American writers): Octavio Paz, Jorge Edwards, Carlos Franqui, Enrique Krauze, José Miguel Oviedo, Rodolfo Pastor, Carlos Rangel, Gabriel Zaid, Juan E. Corradi, Ernesto Sabáto (a dialogue). Published by the Foundation for the Study of Independent Social Ideas (Irving Howe, chairperson).

Order (payment must be enclosed; no billing) from

FSISI

521 Fifth Avenue

New York, N.Y. 10017 